\title{
The Administrative Costs of Local Government Property-Based User Charges and Their Regressivity*
}

\author{
UDK: 332.2:352(497.5) \\ Helena Blažić \\ University of Rijeka, Faculty of Economics, Croatia \\ helena@efri.hr \\ Sandra Stašić \\ City of Rijeka \\ sandra.stasic@rijeka.hr \\ Saša Drezgić \\ University of Rijeka, Faculty of Economics, Croatia \\ sdrezgic@efri.hr
}

\section{ABSTRACT}

The paper measures the administrative costs (assessment and collection costs) of immovable property user charges in local governments in Croatia. This study represents a small scale survey comprising mostly small local governments. First, we establish their costs structure and then we compare the cost-revenue ratio with their size. As expected, the administrative costs of the analyzed user charges turned out to be regressive in regards to the size of local governments.

The results imply that substitution of those different charges would be beneficial for local government budgets. In order to mitigate the problem we propose several alternatives: one general tax/charge; amalgamation of the smallest local governments or referring to assessment and collection of user charges in small local governments to the larger/mutual unit.

\footnotetext{
* The presented results are part of the scientific project Strategy of Socioeconomic Relations of the Croatian Society, No. 081-0000000-1264 supported by the Ministry of Science, Education and Sports of the Republic of Croatia.

Blažić, H., Stašić, S. \& Drezgić, S. (2011). The Administrative Costs of Local Government Property-Based User Charges and Their Regressivity. Uprava IX(4), 7-25.
} 
Keywords: administrative costs, user charges, local government, immovable property

JEL: H27, HTI

\section{Introduction}

The research on operative costs of taxation (administrative and compliance costs of taxation) relates to the third element of tax burden the so called "hidden" costs of the tax system. These costs accrue to the "visible" taxes actually paid and "excess burden" of taxation (deadweight welfare loss).

Administrative and compliance costs in particular, in the last fourty years, have been the subject of growing interest in developed countries'. The same trend is now present in transitional countries ${ }^{2}$ as well as in Far East $^{3}$ and India (Das-Gupta, 2006). ${ }^{4}$

As it has already been addressed, more attention was devoted to compliance than administrative costs, probably due to the rising tax complexity and resulting burden for the private sector (however, the rising interest of public sector efficiency in recent times is one of the reasons why these costs should also be further investigated). One of the most striking conclusions to be drawn from tax compliance literature, which became the mutual result for most of those surveys, was the one about the

1 For instance Sandford, Godwin, Hardwick \& Butterworth, 1981; Sandford, Godwin \& Hardwick, 1989; Bannock \& Albach, 1987 (acccording to Bannock, 2001); Sandford \& Hasseldine, 1992 (acc. to Hasseldine, 1995); Allers, 1994; Pope, Fayle \& Chen, 1994; Pope, 1995; Evans, Ritchie, Tran-Nam \& Walpole, 1997; Collard \& Godwin, 1999; Hudson \& Godwin, 2000; Tran-Nam, Evans, Ritchie \& Walpole, 2000; Gurd \& Turner, 2001; OECD, 2001; Ritchie, 2001; Slemrod \& Venkatesh, 2002; Commission of the European Communities, 2004; Vaillancourt and Clemens, 2008;... This list focuses on business units research (instead of that focused on individuals), since the regressive effect of compliance costs analysis in this research will also be applied to local governments. However, similar regressive effect (depending on the income level) is presented in numerous compliance costs researches covering individuals and their personal income taxes well. Furthermore, the same effect is presented concerning negative taxes also grants submission and reporting process (McGregor-Lowndes \& Ryan, 2009).

2 For instance Klun, 2002 and 2004; Blažić, 2004 and 2004a; Bratić \& Pitarević, 2004; Vitek, Pavel \& Pubal, 2003; Klun \& Blažić, 2005.

3 The synthesis of such studies is given in Ariff, 2001 . Some small scale studies are covered in Bannock, 2001.

4 There are also some studies from the rest of the world. For one of the most exhaustive list of the studies see Evans, 2003. 
regressivity of those costs that disproportionally burden small business units. Furthermore, even small business tax compliance costs are found to be regressive. The same pattern of regressivity that was internationally proven to be true for the entire range of businesses holds for the subgroup of the small business units as well. This is in accordance with the literature that shows that the regressive effect of compliance costs is especially emphasized at the lower end of the size scale ${ }^{5}$.

A smaller number of administrative cost surveys have not addressed this question specifically. Furthermore, those studies deal mostly with tax administration and the central government. The researches mostly encompassed taxes (the social security contributions were usually also included, which are regarded as taxes in the broader sense).

Our research deals with certain aspects of administrative costs that were either not covered before or covered just very lightly: local governments and their administration (instead of tax administration in general which was mostly covered); user charges (instead of taxes); and finally, the regressivity of administrative costs (instead of the compliance ones), causing a significantly higher burden on small local governments. The user charges in the research are those related to immovable property. Their conceptual element, which allows regarding them as taxes (instead of charges) or proposing their substitution with taxes are taken into consideration as well.

The aim of the paper is to measure the administrative costs of presented user charges in relative terms (using classical cost/revenue ratio) and to determine the relationship between this ratio and the size of local governments. It is presumably believed that such costs are regressive in the same manner as the compliance costs of companies of different size.

The methodology described above is applied to the data gathered by an e-mail survey. It is a small scale survey ${ }^{6}$ and since it encompasses smaller local governments, the only big city has been removed from the sample prior to the analysis as an outlier.

5 See previous footnotes and especially OECD 2001.

6 The results of small scale tax compliance costs surveys, which followed the large-scale ones yielded similar results (for instance Bannock, 2001). That is why small scale surveys could be relevant for this type of research and it is reasonable to assume that the same holds for the administrative costs of taxation (and user charges) also. 
The paper is outlined as follows. After the introduction, we briefly describe the user charges related to immovable property in Croatia, within which administrative costs were measured. The third part of the paper explains methodological issues and the fourth one deals with the results (administrative costs structure, their cost-revenue ratio, the relationship between cost-revenue ratio and size, revenue policy proposals for local governments). As usual, concluding remarks are at the end of the paper.

\section{Local government user charges related to immovable property in Croatia}

Local government user charges that are related to immovable property and collected by the local governments (cities and municipalities) in Croatia are as follows: communal charge ${ }^{7}$ communal contribution, historical monuments rent and water regulation charge. The first two charges are of the biggest fiscal importance and comprise about $17 \%$ of all the local government revenues in Croatia (http://www.mfin.hr/hr/lokalni-proracun-2002). The last one is just collected by the local government on behalf of the public enterprise "Croatian waters" that belongs to the central government in the broader sense.

\subsection{Communal charge}

Formally, the Croatian tax system does not include a general recurrent tax on immovable property (property tax), which is common to most other countries ${ }^{8}$. However, the communal charge could be regarded rather as some sort of simple property tax than user charge, based on its real characteristics and taxes / user charges definitions. After presenting its legal characteristics, the reasons for considering it some sort of "tax" will be elaborated briefly.

The communal charge is paid by the owners or users of residential and business buildings (including garages), developed land used for business purposes and undeveloped land for building purposes. The amount paid per $\mathrm{m}^{2}$ is decided by local governments in question without

7 "Communal (charge)" could be translated as "public utilities charge" or "municipal (economy) charge". The same refers to "communal contribution". Here the exact wording "communal" will be maintained.

8 However, Croatian tax system includes tax on holiday houses and tax on the use of public land as some partial forms of immovable property taxation. 
any special limits imposed by the central government (unlike the local taxes). The amount of this charge depends on the above stated purposes of real estate use and its location characteristics.

The revenues are strictly earmarked for the purposes of the drainage of storm water, cleaning and maintenance of public areas, maintenance of cemeteries and the maintenance of local roads and public lighting. However, due to the greater autonomy in determining the burden of those charges and their amount (unlike those of the tax ones) they are often misused for other purposes in the scope of local government responsibilities. The fact that its revenues are often (mis)used to finance other local government expenditures (above stated earmarked ones) already implies the need for modification of such revenues and the development of immovable property (real estate) tax.

As it is well known, taxes are compulsory unrequited payments to general government (for instance OECD, 2011, p. 302). They are "unrequited" in the sense that benefits provided by government to taxpayers are not normally in proportion to their payments. The fact that they are "unrequited payments" precisely represents their basic (of course, not the only one) difference in comparison with user charges.

Although seemingly straightforward, the term "user charges" has no set meaning 9 (Richardson, 2005, p. 456-457) and it could be defined broadly as prices that the government charges on identifiable individuals or entities for a service or goods that it controls. More narrowly, they can be defined as prices that government charges to recover its costs of providing special benefits to an identifiable recipient beyond those that accrue to the general public. This narrower definition rests on a distinction between special benefits to individuals and businesses and general benefits to the public.

This distinction is, of course, clearer in theory than in practice, but exactly in the case of Croatian communal charge it is obvious. Furthermore, the users are not charged according to the benefits they get from the financed public utilities described above and it is not possible to exclude any non-payer from those public utilities. Therefore, these payments seem to be "unrequited". However, there is another benefit here

9 User charges are commonly accepted term, although there is no formal definition existing compared to those of taxes. The definition used here is taken from the Taxation and Tax Policy Encyclopedia, based on the US federal agencies. 
- the one related to the higher value of local real estate due to the higher level of services / public utilities listed above (as well as other local services). It is well known that this is the inherent characteristic of classical local real estate (immovable property) taxes, making them closer to the property related user charges again.

In general, it is not easy to distinguish between those user charges which have features of taxes and those which do not. While a charge is levied in connection with a specific service or activity, the strength of the link between the charge and the service provided may vary considerably. The same refers to the relation between the amount of the fee and the costs of providing the service. Where the recipient of a service pays a fee clearly related to the cost of providing the service, the levy may be regarded as requited (non-tax). The levy could be considered as "unrequited" especially in the cases (OECD, 2011, p. 303) where the charge greatly exceeds the costs of providing the service, where a payer is not the receiver of the benefit, where government does not provide a specific service in return for the levy or where benefits received are not in proportion with the payments.

It could be concluded that Croatian communal charge is some sort of simple property tax, which is not based on its value, but size, purpose/sort and location, depending on the municipality in question. Although it is usual for immovable property taxes to be based on the property value, according to the OECD (OECD, 2011, p. 311) property taxes could be levied in terms of other characteristics of real property (for example size or location), from which a presumed rent or capital value can be derived. Therefore, this charge could be regarded as tax.

Recently, there have been many advocators for the introduction of a classical (value based) property tax in Croatia. It is often neglected that such a tax, if introduced, should not be added, but substituted for the communal charge (and potentially some other charges in question).

\subsection{Communal contribution}

The same local public ("communal") infrastructure listed above is financed by the earmarked revenues from communal contribution charges. However, communal contribution charges finance the construction of that "communal" infrastructure. In addition, the revenues 
based on communal contribution charges cover the costs related to the land where such infrastructure is situated as well as its relocation.

The contribution is paid by the owner of the land upon which the new building is built (or by the investor), who, in this way, directly participates in the building costs of such communal infrastructure.

The amount paid is decided by the local government and is based on similar elements as in the case of communal charge. The zone coefficients here reflect the level of development of relevant local infrastructure. However, the funds are strictly earmarked and even refundable to the payer if the local infrastructure is not built/developed completely according to the planned programme (in the proportion that local infrastructure reflects the building programme goals). So, this contribution really represents the user charge.

\subsection{Historical monuments rent}

Unlike the former user charges, the revenue from this charge is divided between the relevant local government $(60 \%)$ and the central government (40\%).

This charge is based on the assumption that historical monuments could increase the profit of business entities. It is paid by corporate/personal income taxpayers that use the historical monument to increase their revenue. This relates to cases when businesses are situated inside or in the area of the cultural-historical unit. This "rent" is again paid per $\mathrm{m}^{2}$ where the amount per $\mathrm{m}^{2}$ is decided by the local government, but inside the limits set by the central government. Such rent is denoted as "direct" and it is related to the user charge concept. Its revenues are, of course, earmarked.

Another form of user charges is the "indirect" historical monument rent that is paid again by corporate/personal income taxpayers, but only for specific activities (trade, hotels, traffic, banks and financial institutions, betting and gambling, services) regardless of their location. It is paid on their turnover (amount of revenues) charged by the rate of $0,05 \%$. The revenues are again divided between the local government $(56 \%)$ and the central government (44\%). It is obvious that the concept of this rent is more closely related to the (of course earmarked) tax rather than the user charge. 


\subsection{Water regulation charge}

There are as many as eight water charges in Croatia and revenues from them belong to the public enterprise/corporation "Croatian waters".

This water charge is collected by local governments along with the communal charge and paid per $\mathrm{m}^{2}$.

The amounts paid per $\mathrm{m}^{2}$ are set by the central government and differ according to the real estate purpose. The revenues are, of course, earmarked ${ }^{10}$ and used at the territory where they are collected.

Local governments receive a fee on the level of $5 \%$ of revenues collected for this collection service on behalf of Croatian waters. The main idea was to save the administrative costs by collecting both charges together and reimbursing local governments for such service. However, the stated $5 \%$ rate of the fee turned out to be insufficient for covering the assessment and collection costs for smaller local governments. This is the reason why the territorial Croatian waters affiliates that posses the real estate evidence do the water regulation charge assessment and collection process on their own.

\section{Methodology}

\subsection{The survey}

The survey encompassed the costs of assessing the amount of immovable property user fees due as well as all costs related to the collection of user fees, which altogether could be regarded as the administrative costs of user fees. The fees/charges covered were: communal charge, communal contribution, historical monuments rent and water regulation charge.

The survey questionnaire was sent by e-mail to all local governments (cities and municipalities) for which an e-mail address was available (around $97 \%$ of all units) ${ }^{11}$. The e-mail address availability was chosen because it is the easiest and cheapest way to gather data and because it enabled coverage of almost all local governments (due to the stated high percentage). However, the remaining $3 \%$ of local governments

10 Flood protection, melioration, land acquisition...

11 At the time of the research there were 556 local governments (cities and munipalities altogether) (Republic of Croatia, Central Bureau of Statistics, 2009, p.59).

14 Uprava, letnik IX, 4/2011 
(municipalities mostly) were expected to be less developed, which could lead to higher administrative costs also. They were also expected to be among non-respondents.

The questionnaire contained two groups of questions. The first group of questions contained general questions about the size of the local government unit, the number of employees and departments, average wage and budget size. The second group of questions contained detailed questions about organizational elements, indebtedness and user charges collection as well as administrative costs specified by sort ${ }^{12}$.

Out of 536 survey questionnaires sent by e-mail only 35 were returned, resulting in a response rate of only $6,5 \%$. That definitely classifies the survey as being the "small scale". Although most earlier surveys of similar costs (tax compliance costs of business unites) were predominantly large-scale ones (see footnote 1), the results of small scale tax compliance costs surveys, which followed the large-scale ones yielded similar results (Bannock, 2001). However, a very low response rate raises questions about the reliability of the findings. They are relevant under condition that relatively small number of respondents reflects (at least in general) the population (local government units: cities and municipalities). In general, we argue that this is true concerning the teritorial scope as well as different organizational forms of property based user charges collection, and even concerning the units's size (explained more briefly at the end of this chapter). No additional research (in the form of short survey with only one or a couple of questions) was performed later in order to find out whether the non-respondents tend to have higher costs or different cost structure. However, it is reasonable to expect that the respondents were a little bit better organized and to expect that their costs were lower (and even revenues higher) in comparison with the nonrespondents. In addition, the non-responents could mildly influence not only average costs and other cost structure data (Figure 1), but also their cost-revenue ratios (Figure 1 and 2). Still, it is reasonably to believe that the same regressive pattern would be present if the non-respondents were included, perhaps with the generally mildly lower "efficiency" data.

Unfortunately, eight of the questionnaires returned were filled out inappropriately or contained wrong/missing data, and therefore, had to

12 The value of time spent was calculated according to the gross wage and number of working hours. 
be excluded as well. The data for one (big) city was added using the original data and face to face interviews. ${ }^{13}$

It is interesting to point out that mostly smaller local governments returned the questionnaire. Looking at the number of employees around $30 \%$ of them have up to 5 employees and around $60 \%$ from 6-50. Concerning their population, even $70 \%$ of them have less then 5.000 inhabitants and almost $80 \%$ have less than 10.000 inhabitants (the rest up to 50.000). But it is interesting that this structure reflects the population in question pretty accurately, so that the small local units are not overrepresented in the sample. On the contrary, even around $85 \%$ of local units (cities and municipalities) have less than 10.000 inhabitants. However, the absolute number of the bigger (10.000-50.000) local units was too low for the sample to be representative for the entire population and this was especially true for the only one big town (more than 100.000 inhabitants), which was later excluded from the sample (Figure 3). Thus, the average structural data in absolute numbers (Figure 1) should be taken with great reserve. For that reason we point out the average structural data in percentage terms. They are even more reliable, because it is also established that the percentages do not differ greatly with the change in local units' size.

\subsection{Cost - revenue ratio and size}

The efficiency of real estate user charges from the local administration's point of view engaged in their assessment and collection was measured by the ratio of total administrative costs of those local governments and total revenues collected (administrative costs as percentage of revenues collected).

Usually, similar analyses - those concerning administrative costs of taxation (costs of tax administration or similar additional units such as customs administration etc.) were done at the level of aggregate tax administration, since it is very hard to attribute those costs to the lower organizational units (departments or territorial units of tax administration). In those researches the disaggregation was not necessary, since the studies were dealt by the general government level only.

13 One of the authors is employed in the stated big city administration, so its official data as well as face to face interviews were used to add this unit into the the survey data.

16 Uprava, letnik IX, 4/2011 
Here we have a different case, since we compare different local governments. Such approach implies an interesting relationship between their cost-revenue ratio and size.

Since the revenues collected and used as an element of classical costrevenue ratio also signify the size of the local governments ${ }^{14}$ (representing some sort of their "turnover" in comparison to the compliance costs of taxation of business units), that data could also be used for determining the relationship between them.

However, some elements of the standard criticism for "costs as a percentage of revenue" as an efficiency indicator should be taken into account (Sandford, Godwin \& Hardwick, 1989, p. 19-21), which, in this study, particularly refers to revenue as a size indicator as well. In regards to that, there are two problems. First, the ratio is dependent on the tax/charge rate, which is set by the local governments for the first two of the listed four revenues, which form the bulk of the immovable property charges revenues. However, although the zone coefficients for the most important revenue - communal charge differ significantly (the range of the charges can be fivefold, comparing the most attractive zones of some cities), this element should not be observed in isolation, without taking into consideration zone areas, as well as their number and dispersion ${ }^{15}$. Looking at the differences in rates altogether coupled with the numerous differences in other elements of charges, the entire differences in burden are not as striking as they appear at first sight.

The second problem relates to the proportion of revenues collected from potential revenues. The differences between small local governments are not that large; however, the percentage is significantly higher for the big city in the sample, making it even "bigger" and "more efficient" than the rest of the units. Nevertheless, this and the above stated reason(s) present the additional element in favour of excluding it from the sample analysis, as described in the next chapter.

14 The amount of those revenues is positively correlated with the size of the local governments as well as the number of employees. They are not the funcion of value (as "proper'"' real estate taxes), which should imply higher revenues for the real estates in the coastal area for instance. However, they are disproportionally higher for big towns, which will be addressed later.

15 For instance, the highest coefficient of communal charge for the first zone in the big city in our sample is even $2,4 \%$ higher than the average one, but it is limited to a very narrow area only. The coefficients in other zones are at the level of the Croatian average. 


\section{Results}

\subsection{Administrative costs structure}

Figure 1 presents the average structure of measured administrative costs. It is interesting to point out that unit size does not significantly affect the cost structure.

Figure 1: The structure of administrative costs (in Croatian kunas and in percent)

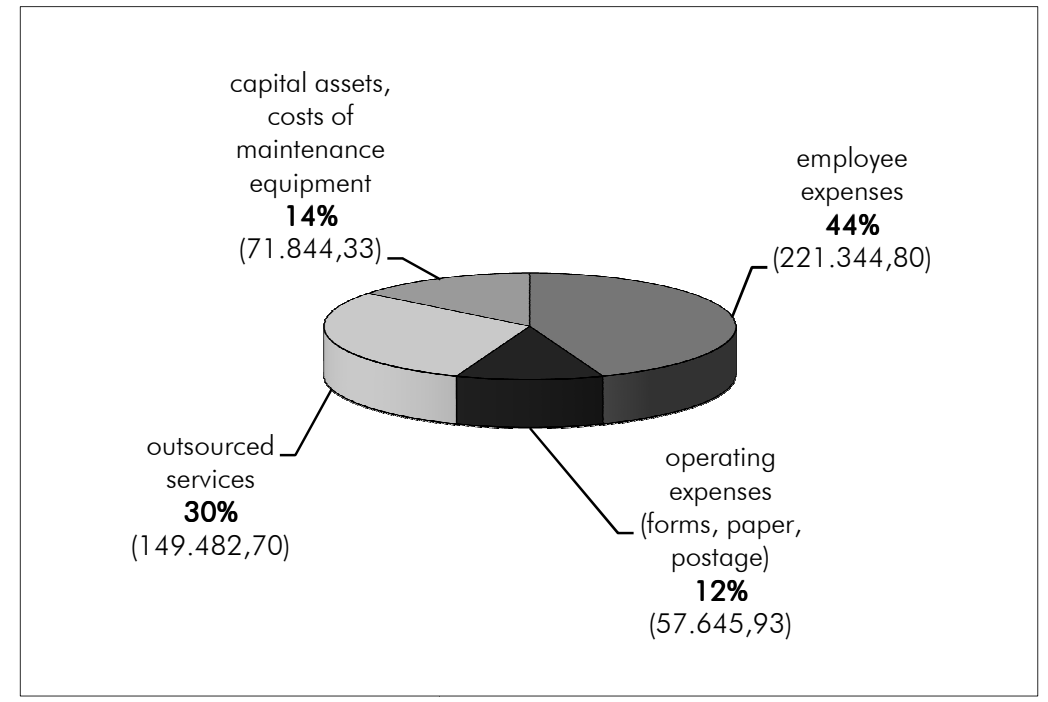

Source: Survey data

Employee expenses participate with the largest share in total costs (almost half of them), which is completely expected, since their services comprise the major part of such costs. Outsourced services comprise the second largest share in total costs and participate with one quarter, followed by the cost of capital assets and equipment maintainance as well as operating expenses.

As it has already been pointed out, the pattern of the cost structure in relation to size does not change in time.

\subsection{Regressive effect of administrative costs}

The relationship between the administrative costs of immovable property user charges as the percentage of their revenue collected and the local government size (measured as those revenue collected) is based on the assumption that the rise in size (revenue) decreases the percentage of administrative costs in those revenues. The influence of the amount 
of revenue on the stated percentage is explained by the double logarithm regression model $Y=\alpha^{*} X^{b}$. That model directly determines the elasticity of the dependent variable (administrative costs as a percentage of revenues) in relation to the independent one (user charges revenues in 000 of Croatian Kunas). The stated relationship is presented in Figure 2.

\section{Figure 2: The relationship between the administrative costs of user charges and their revenue}

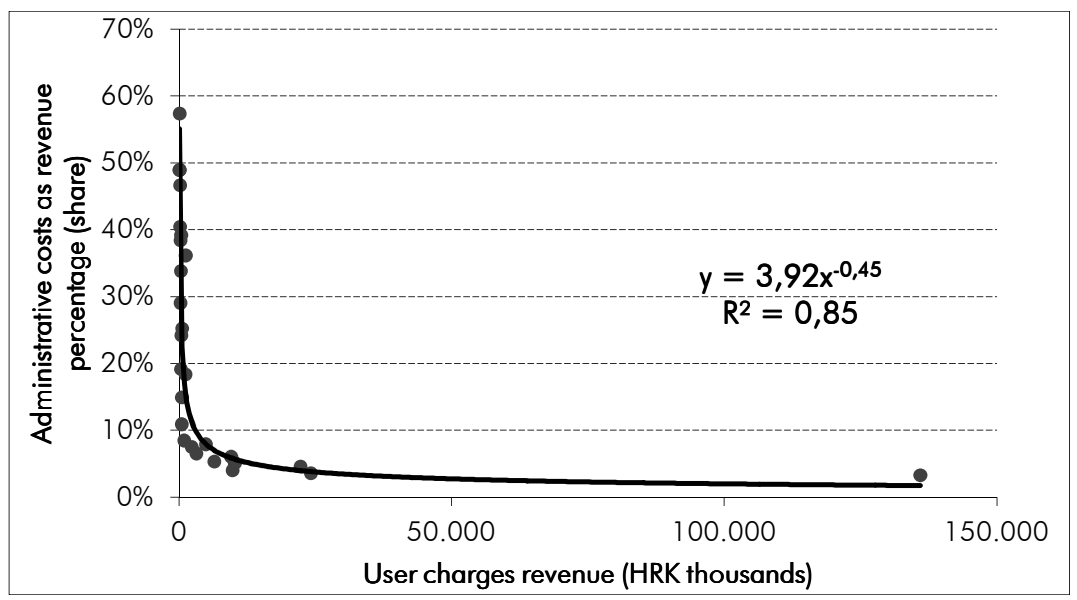

Source: Survey data

Model equation: $Y=3,9161 X^{-0,45}$

The figure is constructed by using the logarithm values of data from the survey. It is obvious that the rise in revenues results in the sharp decline of the cost percentage $\left(R=0,9213 ; R^{2}=0,8488 ; p<0.01\right)$. Even a $84,88 \%$ variation in the cost size could be explained by the amount of revenues.

That implies the regressive nature of those costs in relation to size (similar as with the compliance costs of taxation). This is due to the fixed element of those costs regardless of their size and implies the competitive disadvantage of smaller governments, which is especially strong at the beginning as can be seen from the line slope (the relationship between variables is exponential).

The results also show that it is meaningless to calculate the "average efficiency" (the percentage of costs in revenues) since the range of data is very broad and takes values from $5 \%$ to $50 \%$. 
However, one local government - of course the only real big city in the sample, has enormously high revenues not only in comparison to the average revenue but also in comparison with the second largest local government (even seven times higher) ${ }^{16}$. We follow the usual econometric procedure of removal of outliers. That is why this city is not included in further analysis and that results in the following regression (Figure 3). In such way we restrict our analysis to small local governments. This finding clearly shows that larger cities have to be analysed under separate quantitative analysis. This can be explained by substantial fiscal disparities between larger and smaller local governments in Croatia. Therefore, mixing local governments of different size might give us misleading findings on the issue of administrative costs.

Figure 3: The relationship between the administrative costs of user charges and their revenue for small local governments

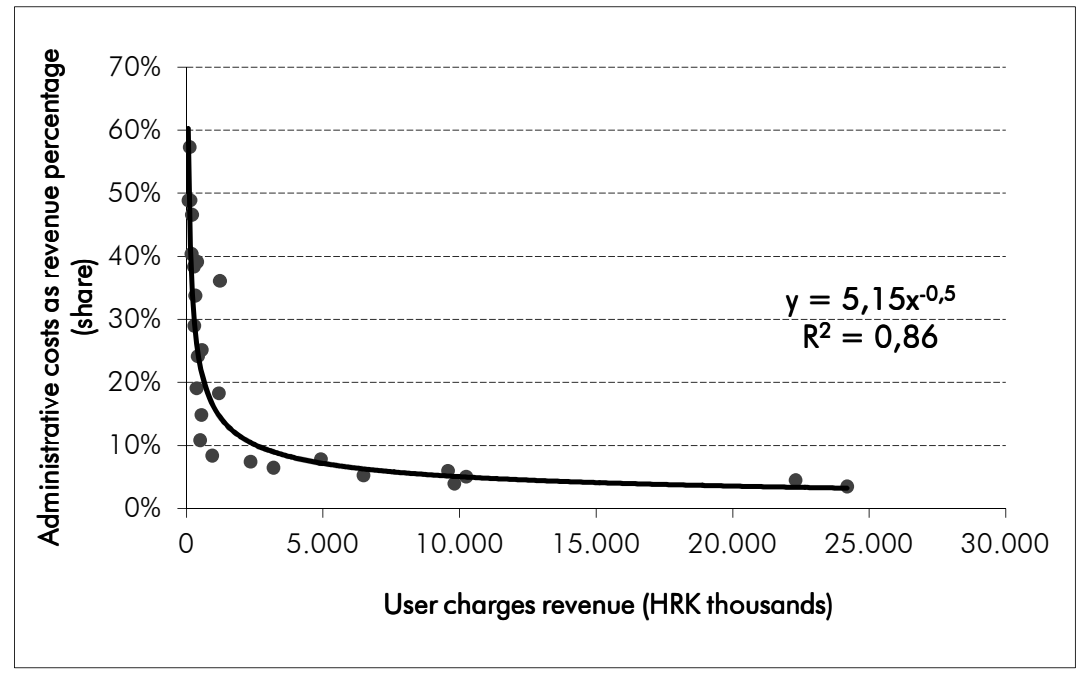

Source: Survey data

Model equation: $Y=5,1561 X^{-0,5019}$

It is obvious that the exemption of the big town results in a rising slope within the equation ${ }^{17}$. This can be explained by the fixed elements of costs and the resulting economy of scales. Even a minor rise in goodness

16 Its inclusion makes the curve falling sharply at the beginning and beeing more skewed at its end.

17 Again, $p<0,01$. 
of fit $\left(R^{2}\right)$ indicates a very high level of adjustments to the calculated values with the real data.

The results indicate the regressive effect of administrative costs of immovable property user charges. Costs are clearly regressive with small local governments bearing a significantly higher burden, especially the smallest ones. Namely, as it is well known from the literature, the regressive effect of compliance costs is particularly emphasized at the lower end of the size scale (it is slightly milder at the upper end of the scale). This is proven here as well.

The possible solutions for those results (presented in the concluding remarks) are in line with the theoretical models pointing out that wthe larger the public sector, and thus the tax revenue, the more taxes there should be " (Yitzhak, 1979, p. 475). It could be easily concluded that in the case of small (local) public sector units the vice versa is relevant and that, of course, the same conclusion applied to taxes could also be relevant for user charges. So, the possible solution(s) could be based either on "less" taxes/user charges or "larger" public sector units, as presented below.

\section{Conclusion}

It is widely known that the compliance costs of taxation are regressive in relation to the size of business taxpayers.

The same is true in the case of user charges (instead of taxes), their administrative costs (instead of compliance ones) and different local governments (instead of business units). Although our research is focused on user charges related to immovable property only (with their administrative costs being completely borne by the local governments), it is obvious that its results could be broadened.

The results of the research suggest two possible reform alternatives. The first one is the substitution of all those charges with one single charge or local property tax, which would be expected to reduce the administrative costs for the local governments. However, the assessment based on the value of property could raise additional administrative costs (the initial ones in particular). That requires comparative analysis of such savings and the new costs that might result. 
The second one relates to the integration of small local governments in general, or only concerning their charges/taxes assessment and collection units in order to avoid/mitigate the negative regressive effects of administrative costs for those smallest units. The need for such reforms is not only addressed by the limited analysis in this research but also by the regressive effect of other types of costs that burden the smallest local governments.

Helena Blažic, PhD is a full professor at the Faculty of Economics, University of Rijeka, teaching Public finance, Comparative Tax Systems, Business taxation, Tax systems of the EU. She is also a visiting professor at the Faculty of Administration, University of Liubliana and Faculty of Economics, University of Split. She has been the team leader and participant in several projects for the Croatian Ministry of Science, Education and Sport, CERGE-El, Prague, Global Development Network and Jean Monnet. She was a visiting fellow at the University of Klagenfurt and University of Kentucky, the head of the MPA programme and is currently the head of the International Cooperation Committee of the Faculty of Economics, University of Rijeka. She is the author of more than 60 publications mostly in the field of tax system and policy.

Sandra Stašić obtained her MSc 2010 in the field of economics, finance at the Faculty of Economics, University of Rijeka, Croatia. She works at the City Department for Public Utilities, City of Rijeka as Head of Office for municipal services payment. From 1999-2002 she worked as an accountant for the companies "Transact" and "Termag" in Rijeka as well as in her own accounting firm. From 1995-1999 she was an IT system consultant in the company Brodomaterijal in Rijeka and a sales specialist for the company Montoprema in Pula.

Sasa Drezgic obtained his PhD in 2008 in the field of public finance at the Faculty of Economics, University of Ljubliana. He works at the Faculty of Economics, University of Rijeka, Croatia, as assistant professor at courses Public finance, Fiscal policy and Economics and policy of investments. Since 2002 he has been team leader and participant in several projects for the Croatian Ministry of Science, Education, and Sport, the Urban Institute and UNDP in the field of public finance and especially field of intergovernmental fiscal relations. In 2009 and 2010 he was a visiting fellow at the Global Governance Center at London School of Economics and Political Science. He is the author of more than 30 publications in the field of fiscal policy, local government finance, public investments and infrastructure finance and economic development issues. 


\section{References}

- Allers, M. (1994). Administrative and Compliance Costs of Taxation and Public Transfers in the Netherlands. Groningen: Woltersgroep.

- Ariff, M. (2001). Compliance cost research in selected Asian economies. In: Evans, C., Pope J. \& John, H. (Eds.) Tax Compliance Costs: A Festschrift for Cedric Sandford. Prospect Media Pty Ltd.

- Bannock, G. (2001). Can small scale surveys of compliance costs work? In: Evans, C., Pope J. \& John, H. (Eds.) Tax Compliance Costs: A Festschrift for Cedric Sandford. Prospect Media Pty Ltd.

- Blažić, H. (2004). Tax Compliance Costs of Companies in Croatia. Ekonomicky časopis - Journal of Economics 52(6), 723-738. Bratislava.

- Blažić, H. (2004a). Troškovi oporezivanja poslovnih subjekata koji su obveznici poreza na dohodak. Financijska teorija i praksa / Financial theory and practice 28(3), 309-324.

- Bratić, V. and Pitarević, M. (2004). Troškovi poreznih vlasti u Hrvatskoj. Financijska teorija i praksa 28(3), 377-401.

- Collard, D. \& Godwin, M. (1999). Compliance Costs for Employers: UK PAYE and National Insurance. Fiscal Studies 20(4), 423-449.

- Commission of the European Communities. European Tax Survey. Commission Staff Working Paper. SEC(2004) 1 128/2. Brussels.

- Evans, C., Ritchie K., Tran-Nam, B. \& Walpole, M. (1997). A Report into Taxpayer Costs of Compliance. Canberra: Australian Government Publishing Service.

- Evans, C. (2003). Studying the Studies: An overview of recent research into taxation operating costs. eJournal of Tax Research 1 (1), 64-92.

- Das-Gupta, A. (2006). Income Tax Compliance Costs of Corporations in India 2000-01. Vikalpa: The Journal for Decision Makers 31 (2), 9-30.

- Gurd B. \& Turner, J. L. (2001). Tax Compliance costs research - a cost management perspective. In: Evans C., Pope J. \& John H. (Eds.) Tax Compliance Costs: A Festschrift for Cedric Sandford. Prospect Media Pty Ltd.

- Hasseldine, J. (1995). Compliance Costs of Business Taxes in New Zealand. In: Sandford, C. (Ed.) Tax Compliance Costs Measurement and Policy. Bath: Fiscal Publications.

- Hudson, J.\& Godwin, M. (2000). The Compliance Costs of Collecting Direct Tax in the UK: An Analysis of PAYE and National Insurance. Journal of Public Economics 77(1) 29-44. 
- Klun, M. (2002). Troškovi ispunjavanja porezne obveze u Sloveniji.

Financijska teorija i praksa / Financial Theory and Practice 26(4), 775-792.

- Klun, M. (2004). Taxation compliance costs for companies in Slovenia. 6th International Conference on Tax Administration: Challenges of Globalising Tax Systems. Sydney: Australian Taxation Studies Program (ATAX), Faculty of Law, The University of New South Wales.

- Klun, M. \& Blažić, H. (2005). Tax Compliance Costs for Companies in Slovenia and Croatia. FinanzArchiv 61 (3), 418-437.

- McGregor-Lowndes, M. \& Ryan, C. (2009). Reducing the Compliance Burden of Non-profit Organisations: Cutting Red Tape. The Australian Journal of Public Administration 68(1), 21-38.

- $\quad$ OECD (2001). Businesses' Views on Red Tape. Paris: OECD.

- OECD (2011). Revenue Statistics 1965-2010. Paris: OECD.

- Pope, J. (1995). The Compliance Costs of Major Taxes in Australia. In: Sandford, C. (Ed.) Tax Compliance Costs Measurement and Policy. Bath: Fiscal Publications.

- Republic of Croatia, Central Bureau of Statistics (2009). Statistical Yearbook 2009 .

- Richardson, P. (2005). User charges. In: Cordes, J. J. et.al. (Eds) The Encyclopedia of Taxation and Tax Policy, 2nd. ed. (456-458). Washington, DC: The Urban Institute Press.

- Ritchie, K. (2001). The Tax Compliance Costs of Small Business in New Zealand. In: Evans, C., Pope, J. \& Hasseldine J. (Eds.) Tax Compliance Costs: A Festschrift for Cedric Sandford (297-315). St Leonards: Prospect Media Pty.

- Sandford, C. T., Godwin, M. R., Hardwick, P. J. W. \& Butterworth, M. I. (1981). Costs and benefits of VAT. London: Heinemann Educational Books.

- Sandford, C., Godwin, M. \& Hardwick, P. (1989). Administrative and Compliance Costs of Taxation. Bath: Fiscal Publications.

- Sandford, C. (Ed.) (1995). Tax Compliance Costs Measurement and Policy. Bath: Fiscal Publications.

- Slemrod, J. B. \& Venkatesh, V. (2002). The Income Tax Compliance Cost of Large and Mid-Size Businesses. Ross School of Biness Paper No. 914. Available at: http://ssrn.com/abstract $=913056$.

- Tran-Nam, B., Evans, C., Ritchie, K. \& Walpole, M. (2000). Tax Compliance Costs: Research Methodology and Empirical Evidence from Australia. National Tax Journa/ III(2), 229-252. 
- Yitzhaki, S. (1979). A Note on Optimal Taxation and Administrative Costs. The American Economic Review 69(3), 475-480.

- Vaillancourt, F. \& Clemens, J. (2008). Compliance and Administrative Costs of Taxation in Canada. In: Clemens, J. (Ed.) The Impact and Cost of Taxation in Canada: The Case for Flat Tax Reform (55-102). Fraser Institute.

- Vitek, L., Pavel, J. \& Pubal, K. (2003). Effectiveness of the Czech Tax System - Administrative and Compliance Costs Measurement. IIPF Congress. Prague.

- $\quad$ http://www.mfin.hr/hr/lokalni-proracun-2002 


\title{
POVZETEK
}

\section{UPRAVNI STROŠKI LOKALNIH SAMOUPRAV S TAKSAMI ZA UPORABNIKE NEPREMIČNIN IN NJIHOVA DEGRESIVNOST*}

\author{
Ključne besede: administrativni stroški, takse za uporabnike, lokalna \\ samouprava, nepremičnine
}

Za stroške upravljanja in predvsem skladnosti je $v$ zadnjih 40 letih vse več zanimanja. Več pozornosti se namenja stroškom skladnosti ko† upravnim stroškom, verjetno zaradi vedno večje kompleksnosti davkov in posledične obremenjenosti zasebnega sektorja (hkrati pa je $\vee$ zadnjem času povečano zanimanje za učinkovitost javnega sektorja razlog, zakaj bi bilo treba tudi te stroške boli podrobno preučiti). Eden od bolj izstopajočih zaključkov na osnovi literature o davčni skladnosti, ki je nastala kot skupen rezultat večine takšnih raziskav, je ugotovitev o degresivnosti tistih stroškov, ki nesorazmerno bremenijo majhne poslovne enote. Poleg tega so se za degresivne izkazali celo stroški skladnosti za majhna podjetja. Enak vzorec degresivnosti, za katerega je na mednarodni ravni dokazano, da velja za celoten podjetniški spekter, prav tako velja za podskupino majhnih poslovnih enot. To je skladno z literaturo, ki kaže, da je degresivni učinek stroškov skladnosti posebno izrazit na nižjem območju velikostne lestvice.

Manjše število raziskav o upravnih stroških se ni podrobno ukvarjalo s tem vprašanjem. Poleg tega te študije večinoma obravnavajo davčno upravo in centralno upravo. Zajemajo predvsem davke (raziskave so običajno vključevale tudi prispevke za socialno varnost, ki se obravnavajo kot davki v širšem smislu).

Pričujoča raziskava se ukvaria z določenimi vidiki upravnih stroškov, ki do zdai še niso bili raziskani ali pa le površno: lokalne samoupravne enote in niihova uprava (namesto davčne uprave na splošno, ki je bila večinoma predmet proučevanja); takse za uporabnike (namesto davkov); in končno, degresivnost upravnih stroškov (namesto stroškov skladnosti),

\footnotetext{
* Predstavljeni rezultati so del znanstvenega projekta Strategija družbenoekonomskih odnosov hrvaške družbe, št. 081-0000000-1264, ki jo je podprlo Ministrstvo za znanost, izobraževanje in šport Republike Hrvaške.
} 
ki majhnim lokalnim samoupravnim enotam nalaga bistveno večje breme.

Ta raziskava obravnava takse za uporabnike, ki so povezane z nepremičninami.

Raziskava manjšega obsega (e-vprašalnik) je zajemala stroške obračunavania zneska plačljivih taks za uporabnike nepremičnin, pa tudi vse stroške $v$ zvezi $z$ njihovim pobiranjem, ki jih lahko skupai obravnavamo kot upravne stroške s taksami za uporabnike. Zajete takse so: komunalne takse (taksa za javne službe, taksa za mestno gospodarstvo), komunalni prispevek (prispevek za javne službe), stanarina za zgodovinske spomenike in taksa za urejanje voda. Vprašalnik so večinoma vrnile manjše enote lokalne samouprave.

Učinkovitost taks za uporabnike nepremičnin s stališča lokalne samouprave, ki se ukvarja z njihovim obračunavanjem in pobiranjem, je bila merjena na osnovi razmerja med skupnimi upravnimi stroški teh lokalnih samoupravnih enot in skupnimi prejetimi prihodki (upravni stroški kot odstotek prejetih prihodkov).

Podobne analize, ki zadevajo upravne stroške obdavčevanja (stroški davčne uprave ali podobnih dodatnih enot, kot je carinska uprava), se ponavadi izvajajo na ravni skupne davčne uprave, saj je te stroške zelo težko razvrstiti po nižjih organizacijskih enotah (oddelkih ali ozemeliskih enotah davčne uprave). $V$ teh raziskavah razčlenjevanje ni bilo potrebno, ker so študije tematiko obravnavale samo na ravni splošne uprave.

Naš primer je drugačen, saj primerjamo različne enote lokalne samouprave. Takšen pristop kaže na zanimivo zvezo med razmerjem stroškov in prihodkov ter velikostjo teh enot.

Ker prejeti prihodki, ki smo jih uporabili kot element klasičnega razmerja med stroški in prihodki, označujejo tudi velikost posameznih lokalnih samouprav (izkazujejo nekakšen "promet" v primerjavi s stroški skladnosti obdavčevanja poslovnih enot), bi tudi te podatke lahko uporabili za ugotavljanje zveze med njimi.

Zveza med upravnimi stroški taks za uporabnike nepremičnin kot odstotkom prejetih prihodkov in velikostjo lokalne samouprave (merjena kot ti prejeti prihodki) temelji na predpostavki, da se ob povečanju velikosti (prihodka) zmanjša odstotek upravnih stroškov iz naslova teh prihodkov. Vpliv obsega prihodka na navedeni odstotek je prikazan z dvojnim logaritemskim modelom degresije $Y=\alpha^{*} X^{b}$. Ta model 
neposredno določa elastičnost odvisne spremenljivke (upravni stroški kot odstotek prihodkov) glede na neodvisno spremenljivko (prihodki od taks za uporabnike).

Številka je pridobljena s pomočjo logaritemskih vrednosti podatkov iz raziskave. Očitno je, da bo s povečanjem prihodkov odstotek stroškov močno upadel $\left(R=0,9213 ; R^{2}=0,8488 ; p<0,01\right)$. Celo 84,88 \% razliko v velikosti stroškov bi lahko pojasnili z obsegom prihodkov.

To kaže na degresivno naravo teh stroškov glede na velikost (podobno kot pri stroških skladnosti za obdavčevanje). To je posledica fiksnega elementa teh stroškov ne glede na njihovo velikost, kar kaže na konkurenčno slabši položaj manjših samouprav, ki je zlasti izrazit na začetku, kot je razvidno iz naklona krivulje (zveza med spremenljivkami je eksponentna).

Rezultati kažejo tudi, da je brez pomena računati "povprečno učinkovitost" (odstotek stroškov v prihodkih), sai je razpon podatkov zelo širok in zajema vrednosti od $5 \%$ do $50 \%$.

Rezultati izkazujejo degresivni učinek upravnih stroškov taks za uporabnike nepremičnin. Stroški so nedvomno degresivni, pri čemer so majhne enote lokalne samouprave bistveno bolj obremenjene, predvsem najmanjše. Iz literature je namreč dobro znano, da je degresivni učinek stroškov skladnosti izrazit predvsem na nižjem območju velikostne lestvice (nekoliko milejši je na višjem območju lestvice). To dokazuje tudi naša raziskava.

Čeprav se pričujoča raziskava osredotoča samo na takse za uporabnike $v$ povezavi z nepremičninami (kjer nijhove upravne stroške $v$ celoti nosijo lokalne samouprave), je očitno, da bi lahko rezultate razširili na druga področja.

Iz rezultatov raziskave izhajata dve možnosti za reformo. Prva je uvedba ena same takse oziroma lokalnega nepremičninskega davka, ki bi nadomestila vse omenjene takse, kar bi predvidoma zmanjšalo upravne stroške lokalnih samoupravnih enot. Po drugi strani pa bi lahko obračunavanje na podlagi vrednosti nepremičnin povzročilo dodatne upravne stroške (zlasti $\vee$ začetni fazi). Zato bi bila potrebna primerjalna analiza ustreznih prihrankov in morebitnih novonastalih stroškov.

Druga možnost se navezuje na povezovanje majhnih lokalnih samouprav $v$ splošno, ali pa vsaj tistih njihovih enot, ki obračunavajo in 
pobirajo takse/davke, kar bi preprečilo/omililo negativni degresivni učinek upravnih stroškov $v$ najmanjših enotah. Potrebnost takšnih reform ne izhaja samo iz omejene analize $v$ tej raziskavi, temveč tudi iz degresivnega učinka drugih vrst stroškov, ki bremenijo najmanjše lokalne samouprave. 